\title{
Do ecological and silvicultural factors influence acorn mass in Holm Oak (southwestern Spain)?
}

\author{
R. Alejano · J. Vázquez-Piqué · F. Carevic • \\ M. Fernández
}

Received: 24 May 2010/Accepted: 8 January 2011

(C) Springer Science+Business Media B.V. 2011

\begin{abstract}
The effect of orientation, location, year, and pruning treatment on mean acorn mass in two open woodland experimental locations (Huelva, South-Western Spain) of Holm Oak (Quercus ilex L. subsp. ballota [Desf.] Samp.) was analyzed during 2001-2006. Data were analyzed by using a mixed linear model, where the covariates were tree size parameters (circumference at $80 \mathrm{~cm}$ height, crown size), topographic position (wet index and flow length), intraspecific competition, total acorn crops per tree (weight and number), and climatic parameters. Average estimated acorn mass was $3.17 \mathrm{~g}$ acorn $^{-1}$ in the Calañas location and $4.12 \mathrm{~g} \mathrm{acorn}^{-1}$ in the San Bartolomé location, with significant differences between locations, among individual trees and across years. Acorns from the south sides of trees were significantly heavier than those at other positions. The effect of pruning treatment and the
\end{abstract}

R. Alejano $(\bowtie) \cdot$ J. Vázquez-Piqué .

F. Carevic · M. Fernández

Agroforestry Department, University of Huelva, Escuela

Politécnica Superior, Campus de La Rábida, Palos de la

Frontera, 21819 Huelva, (Spain)

e-mail: ralejan@uhu.es

J. Vázquez-Piqué

e-mail: jpique@uhu.es

F. Carevic

e-mail: felipe.carevic@dcaf.uhu.es

M. Fernández

e-mail: manuel.fernandez@dcaf.uhu.es interactions location $\times$ treatment and treatment $\times$ year were not significant. Our study provides no evidence that pruning affects acorn mass. None of the analyzed covariates related to tree size, topographic position and intraspecific competition explained the difference among trees, suggesting that heritable factors play an important role. Specific climatic parameters during September, the most important month for acorn growth, may explain the effects of year and location $\times$ year on acorn mass. In addition, there appeared to be a "trade-off" between acorn mass and number of acorns.

Keywords Dehesa Q Quercus ilex . Acorn production

\section{Introduction}

Trees of the genus Quercus are widespread in the northern hemisphere and are significant species in many forests and woodlands (Cañellas et al. 2006, 2007). In the Mediterranean Basin and Middle East, the Holm Oak (Quercus ilex L. subsp. ballota [Desf.] Samp), an sclerophyllous evergreen tree, occurs over an area that extends $6,000 \mathrm{~km}$ longitudinally, from Portugal to Syria, and 1,500 km latitudinally, from Morocco and Algeria to France (Debazac 1983). In the Iberian peninsula, Holm Oak is a very abundant 
species, and covers a total area of about 2.5 million ha (García-Mozo et al. 2007). Holm Oak can occupy diverse ecological niches, and occurs in humid, subhumid, and semiarid regions (Afzal-Rafii et al. 1992). This Quercus species is the dominant in Mediterranean wooded pasturelands of the Iberian peninsula, known locally as "dehesa". Dehesa ecosystems consist of oak woodland (30-50 trees per ha, principal species Quercus ilex and $Q$. suber) with an understory of croplands, grasslands, and shrub lands where cattle, sheep, pigs, and goats are raised (San Miguel 1994).

Acorn production is a key factor concerning the ecology and economy of dehesas. It plays a fundamental role in the organization and dynamics of forest ecosystems, and both annual and individual variation in acorn production influence the regeneration and management of oak forests (Healy et al. 1999). According to Koenig et al. (1994), the size and constancy of acorn crops are not only basic to the life history of oaks, but is also important to the diverse assemblage of birds and mammals that rely on acorns as a major food resource. Carbonero et al. (2008) consider that it also plays a basic role in the dynamics of plagues and diseases in these open woodland forests. In the economics, acorns are used for feeding the livestock, and specifically Iberian pigs, where the quality of their products (meat) and their market value depends on acorn consumption. When acorn dissemination period starts in dehesas, the pigs weight $90-120 \mathrm{~kg}$, and after 3 months they reach 160-180 kg, being acorns and fresh grass the main components of their diet during this time (Consejeria de Medio Ambiente 2004).

Total acorn production (in weight) can be considered as the product of two components: number of acorns and the average acorn mass. All previous studies related with acorn production (Martin et al. 1998; Álvarez et al. 2002; Carbonero et al. 2002; Gea-Izquierdo et al. 2006; Poblaciones et al. 2006; Cañellas et al. 2007; Alejano et al. 2008) have not considered these two components separately. Nevertheless, to get a better understanding of the acorn production process it is very important to analyze both components separately, as silvicultural and ecological factors will affect them differently. Number of acorns will be related with flowering and flower survival processes while acorn weight is related with accumulation of reserve substances in the fruit. It is not a minor issue from the management and ecological point of view to know if a particular silvicultural treatment affect the number of acorns, the weight per acorn or both components, or what are the climatic events that affect the number of acorns or the average acorn mass. This paper is focused on the second component: average acorn mass.

Rodríguez-Estévez et al. (2009) found that at the start of the acorn dissemination period for Holm Oak trees, Iberian pigs preferred larger (longer and wider) and heavier acorns, with high pulp content. At the end of the period, according to Emlen (1966), that selection would be based on acorn composition. Furthermore, for plants, the dependence of offspring fitness on seed size and mass has been extensively documented (Pons and Pausas 2007) and supported by the empirical evidence; larger seeds benefit seedling against competition, herbivory, shading and drought (Bonfil 1998; Bondeau et al. 1999; Jakobsson and Eriksson 2000).

Pruning is a common silvicultural practice in dehesas and typically consists of removing branches in the inner part of the crown. Pruning has traditionally been carried out to obtain fuelwood, but also because it was thought to improve acorn production and acorn mass, probably because opening the canopy implies that the tree receives more solar radiation, what would be supposed to improve flowering and therefore acorn production. However, this hypothesis has been questioned (Carbonero et al. 2002; Cañellas et al. 2006; Alejano et al. 2008) and significant differences in acorn production from pruned and non pruned trees have not been found (Alejano et al. 2008). But the effect of pruning on acorn mass, as a component of acorn production, has not been well documented in these papers.

In this study, acorn mass, as a component of acorn production, was assessed in two experimental locations of Holm Oak in the province of Huelva, south-western Spain, in the interval 2001-2006. The effect of orientation (within the tree), location, year, and pruning treatment on the mean acorn mass were analyzed; the covariates being tree size parameters (circumference at $80 \mathrm{~cm}$ height, crown size), parameters related with topographic position (wet index and flow length), intraspecific competition (with calculation of competition indexes), total acorn crops per tree (in weight and number), and climatic parameters. 


\section{Materials and methods}

\section{Experimental locations}

The present study was conducted in two locations laid out in the province of Huelva (South-Western Spain). The first location was at "La Encarnación y Castilnovo" farm (public property), in Calañas (CA), Huelva (UTM, zone 29: X, 681349; Y, 4156557). The second location was at "El Campillo" farm (private property), in San Bartolomé de la Torre (SB), Huelva (UTM, zone 29: X, 669638; Y, 4145966). Both study areas are located at the southern foothills of the western Sierra Morena and have Mediterranean climate. Tables 1 and 2 describe the mean characteristics of the two locations and tree size parameters. Table 3 summarizes the climatic characteristics of the two locations during the study period.

The areas of the study were fenced to avoid predation by cattle and other higher herbivores. The exact ages of the trees are unknown because locally absent rings and false bands are common in this species (Hidalgo-Fernández and Heras 2003). We estimated age in both locations as being 40-90 yearsold, based on size and historical knowledge of land owners, managers, and forest rangers (Alejano et al. 2008).

Trees in the two locations were subjected to traditional pruning at three different intensities (light, moderate, or heavy) or were unpruned (controls). Pruning was carried out in January 2001 in CA and in February 2003 in SB. All trees had been previously pruned. Trees in CA were pruned in 1994 and those in SB in 1996. In the CA location, we studied 80 trees (20 trees $\times 4$ treatments $=80$ trees) and in the SB location, we studied 100 trees $(25$ trees $\times 4$ treatments $=100$ trees). For both sites, all treatments were randomly assigned to trees. Diameter classes were not taken into account, which means that we had not the same number of trees per diameter class for every treatment. The pruning operation was performed by workers hired by the forest owners. In the absence of previous criteria, the pruning intensity was established as follows: light pruning involved removing sucker and dead branches only; heavy pruning coincided with the usual practice in the area; and moderate pruning was in between the previous two (Alejano et al. 2008). Once work was completed, pruning intensity was estimated as a function of the weight of pruned branches and tree diameter. Pruning
Table 1 Features of the Calañas (CA) and San Bartolomé (SB) locations

\footnotetext{
${ }^{\text {a }}$ Mean values of three sample points at each location
}

Main uses

\begin{tabular}{|c|c|c|}
\hline & Calañas (CA) & San Bartolomé (SB) \\
\hline Area (ha) & 2.9 & 2.7 \\
\hline Density (trees ha ${ }^{-1}$ ) & 34.5 & 36.0 \\
\hline Altitude (m) & 165 & 128 \\
\hline \multicolumn{3}{|l|}{ Climate } \\
\hline Mean annual precipitation (mm) & 727 & 633 \\
\hline Mean annual temperature $\left({ }^{\circ} \mathrm{C}\right)$ & 18.3 & 18.6 \\
\hline Frost period (months) & 4 & 2 \\
\hline \multicolumn{3}{|l|}{ Soils $^{\mathrm{a}}$} \\
\hline Parent material & Slates and graywackes & Slates \\
\hline Stoniness $(\%)$ & 34 & 5 \\
\hline Texture & Silt, silt-clay in depth & Silt, silt-clay in depth \\
\hline Soil depth $(\mathrm{cm})$ & 33 & 67 \\
\hline $\mathrm{WRC}^{\mathrm{b}}(\mathrm{mm})$ & 19 & 41 \\
\hline $\mathrm{pH}\left(\mathrm{H}_{2} \mathrm{O}\right)$ & 5.9 & 6.1 \\
\hline FAO classification & Regosols/Leptosols to Cambisols & Regosols/Luvisols \\
\hline Understory & $\begin{array}{l}\text { Heliophilic bushes } \\
\text { (Cistus ladanifer, } \\
\text { C. monspeliensis) }\end{array}$ & $\begin{array}{l}\text { Herbaceous species } \\
\text { dominant due to soil } \\
\text { ploughing }\end{array}$ \\
\hline Main uses & $\begin{array}{l}\text { Big and small game, livestock } \\
\text { (sheep), mushroom harvesting } \\
\text { (not controlled) }\end{array}$ & $\begin{array}{l}\text { Horses and fighting } \\
\text { bulls raising }\end{array}$ \\
\hline
\end{tabular}


Table 2 Tree size parameters in the Calañas (CA) and San Bartolomé (SB) locations

\begin{tabular}{|c|c|c|c|c|c|c|}
\hline & \multicolumn{3}{|c|}{$\mathrm{CA}(N=80)$} & \multicolumn{3}{|c|}{$\mathrm{SB}(N=100)$} \\
\hline & Min & Max & Average $\pm \mathrm{SD}^{\mathrm{b}}$ & Min & Max & Average $\pm \mathrm{SD}^{\mathrm{b}}$ \\
\hline Height (m) & 2.3 & 9.7 & $6.1 \pm 1.6$ & 4.5 & 9.5 & $6.5 \pm 1.1$ \\
\hline $\mathrm{DH} 80^{\mathrm{a}}(\mathrm{cm})$ & 8.6 & 52.2 & $32.5 \pm 10.7$ & 15.2 & 57.3 & $35.4 \pm 7.2$ \\
\hline Crown radius $(\mathrm{m})$ & 1.9 & 6.0 & $3.8 \pm 1.3$ & 2.8 & 6.6 & $4.4 \pm 1.0$ \\
\hline
\end{tabular}

a Stem diameter at $80 \mathrm{~cm}$ height

b $S D$ standard deviation

Table 3 Climatic variables of the Calañas (CA) and San Bartolomé (SB) locations during the studied period

\begin{tabular}{|c|c|c|c|c|c|c|}
\hline Year & 2001 & 2002 & 2003 & 2004 & 2005 & 2006 \\
\hline \multicolumn{7}{|l|}{ Calañas } \\
\hline $\mathrm{P}(\mathrm{mm})$ & 907 & 717 & 789 & 641 & 351 & 854 \\
\hline Psp (mm) & 42 & 126 & 101 & 93 & 70 & 136 \\
\hline Psu (mm) & 121 & 87 & 27 & 10 & 0 & 93 \\
\hline $\operatorname{Tmax}\left({ }^{\circ} \mathrm{C}\right)$ & 39.3 & 38.2 & 43.1 & 42.3 & 41.1 & 40.4 \\
\hline $\operatorname{Tmmax}\left({ }^{\circ} \mathrm{C}\right)$ & 31.1 & 33.6 & 34.9 & 34.9 & 34.5 & 35.0 \\
\hline $\operatorname{Tm}\left({ }^{\circ} \mathrm{C}\right)$ & 17.2 & 17.0 & 17.3 & 17.2 & 17.1 & 17.2 \\
\hline $\operatorname{Tmmin}\left({ }^{\circ} \mathrm{C}\right)$ & 6.8 & 7.8 & 6.0 & 6.5 & 5.3 & 5.1 \\
\hline $\operatorname{Tmin}\left({ }^{\circ} \mathrm{C}\right)$ & 2.4 & 0.0 & 0.7 & 0.9 & -2.4 & 0.0 \\
\hline \multicolumn{7}{|l|}{ San Bartolomé } \\
\hline $\mathrm{P}(\mathrm{mm})$ & 679 & 721 & 884 & 536 & 362 & 850 \\
\hline Psp (mm) & 34 & 157 & 117 & 109 & 38 & 115 \\
\hline Psu (mm) & 76 & 113 & 10 & 13 & 1 & 99 \\
\hline $\operatorname{Tmax}\left({ }^{\circ} \mathrm{C}\right)$ & 38.8 & 37.4 & 43.4 & 42.9 & 39.2 & 41.1 \\
\hline $\operatorname{Tmmax}\left({ }^{\circ} \mathrm{C}\right)$ & 32.5 & 32.5 & 33.8 & 33.9 & 33.3 & 34.4 \\
\hline $\operatorname{Tm}\left({ }^{\circ} \mathrm{C}\right)$ & 17.4 & 17.3 & 17.5 & 17.4 & 17.1 & 17.4 \\
\hline $\operatorname{Tmmin}\left({ }^{\circ} \mathrm{C}\right)$ & 7.0 & 7.7 & 5.8 & 6.0 & 3.4 & 4.5 \\
\hline $\operatorname{Tmin}\left({ }^{\circ} \mathrm{C}\right)$ & 1.0 & 0.0 & -0.2 & 1.1 & -3.1 & 0.0 \\
\hline
\end{tabular}

$P$ annual precipitation $(\mathrm{mm}), P$ sp spring precipitation $(\mathrm{mm})$, $P$ su summer precipitation (mm), Tmax maximum temperature $\left({ }^{\circ} \mathrm{C}\right), T$ mmax mean of the maximum temperatures of the hottest month $\left({ }^{\circ} \mathrm{C}\right), T \mathrm{~m}$ mean annual temperature $\left({ }^{\circ} \mathrm{C}\right)$, mmin mean of the minimum temperatures of the coldest month $\left({ }^{\circ} \mathrm{C}\right), T \mathrm{~min}$ minimum temperature $\left({ }^{\circ} \mathrm{C}\right)$

treatments were discriminated in terms of intensity by using the branch dry weight (DW) to tree diameter (D) ratio; thus, DW/D was less than 0.8 for light pruning, greater than 1.7 for heavy pruning and in between these two levels for moderate pruning (Alejano et al. 2004). Every Holm Oak harvested for acorns was classified into its original group, so no tree was changed to a different pruning treatment (Alejano et al. 2008).
Estimation of acorn production and acorn mass

Trees used to estimate acorn production were selected by stratified sampling as a function of stem diameter. Each tree was assigned to a diameter (D) class: $\mathrm{D}<25 \mathrm{~cm}, 25 \mathrm{~cm}<\mathrm{D}<40 \mathrm{~cm}$, and D $>40 \mathrm{~cm}$. Diameter was measured at a height of 80 $\mathrm{cm}$. We did not use diameter at breast height (DBH) because "formation pruning" was performed when trees were young, and branches started lower than 1.3 $\mathrm{m}$. Twelve trees were selected for acorn harvesting in the CA location (3 trees per pruning treatment, one per diameter class) and 16 trees were selected for acorn harvesting in the SB location (4 per pruning treatment, one per higher and lower diameter class, and two per middle diameter class).

Acorns were harvested by a trapping method using containers (Greenberg 2000). Four containers ( $0.45 \mathrm{~m}$ diameter at the top) were placed on the soil under selected trees at the north, south, east, and west positions, at three-quarters of the distance from the stem to the edge of the crown. This trapping method allowed us to sample a fraction of the projection of the crown surface from where acorns were assumed to fall. Acorn production as measured with the container method was quite consistent with the total acorn yield harvested in four trees per location (Alejano et al. 2008). Table 4 includes a summary of acorn production in weight and number per location per year. Acorn production in weight and number per tree and orientation will be also calculated and used as covariates in the model described next.

Acorns were harvested during 2001/2002, 2002/2003, 2003/2004, 2004/2005, 2005/2006, and 2006/2007 (i.e., the first 6 years following pruning) in CA, and during 2002/2003, 2003/2004, 2004/2005, $2005 / 2006$, and $2006 / 2007$ in SB. Acorns fell from 
Table 4 Acorn production per tree in weight and number during the studied period

\begin{tabular}{|c|c|c|c|c|c|}
\hline \multirow[t]{2}{*}{ Location } & \multirow[t]{2}{*}{ Year } & \multicolumn{2}{|c|}{ Acorn weight $^{\mathrm{a}}$} & \multicolumn{2}{|c|}{ Acorn number ${ }^{b}$} \\
\hline & & Average & $\mathrm{SD}^{\mathrm{c}}$ & Average & $\mathrm{SD}^{\mathrm{c}}$ \\
\hline \multicolumn{6}{|c|}{ Calañas $(n=12)$} \\
\hline & 2001 & 129.8 & 193.2 & 29.3 & 41.9 \\
\hline & 2002 & 248.6 & 201.6 & 60.5 & 50.7 \\
\hline & 2003 & 232.8 & 262.5 & 79.9 & 62.7 \\
\hline & 2004 & 92.7 & 101.2 & 38.4 & 37.2 \\
\hline & 2005 & 8.2 & 21.0 & 3.3 & 7.6 \\
\hline & 2006 & 29.3 & 50.0 & 8.9 & 14.5 \\
\hline \multicolumn{6}{|c|}{$\begin{array}{l}\text { San Bartolomé } \\
(n=16)\end{array}$} \\
\hline & 2002 & 419.8 & 364.0 & 103.0 & 104.9 \\
\hline & 2003 & 440.5 & 215.0 & 109.1 & 71.6 \\
\hline & 2004 & 85.4 & 77.5 & 19.3 & 19.4 \\
\hline & 2005 & 203.6 & 238.6 & 54.1 & 63.3 \\
\hline & 2006 & 20.0 & 29.8 & 6.6 & 10.0 \\
\hline
\end{tabular}

${ }^{\mathrm{a}} \mathrm{g} \mathrm{m}^{-2}$ of canopy area per tree

b Number of acorns $\mathrm{m}^{-2}$ of canopy area per tree

c $S D$ standard deviation

October to January and were harvested on a fortnightly basis. We considered acorns designated as year 2001 to include those that fell from October 2001 to January 2002, and those for subsequent years to include analogous periods.

All collected acorns (a total amount of 4,407) were put in plastic bags, transferred to the laboratory on the day of harvesting and stored refrigerated at $3^{\circ} \mathrm{C}$ overnight. Next, acorns were counted and fresh weight (FW to within $\pm 0.001 \mathrm{~g}$ ) of every acorn was measured on a precision balance. These data were used to determine average acorn mass in every tree (the addition of the fresh weight of every acorn in the tree divided by the number of acorns collected under the same tree), orientation (the same, taking into account if the acorns were collected in the North, South, East or West container) and year (the addition of the fresh weight of the total amount of acorns collected in the plot and year, divided by the number of acorns collected in the plot and year). Also, total weight of acorns per tree ( $\mathrm{g} \mathrm{m}^{-2}$ of canopy area), per year and by orientation, and total number of acorns per tree (number of acorns $\mathrm{m}^{-2}$ of canopy area), per year and by orientation, were calculated, as needed in the model explained next. In order to determine the water content, WC, of the acorns, 80 fruits (from the 8 trees used for total acorn harvesting, ten acorns per tree) were randomly chosen each month and cut in half to measure their dry weight (DM) following drying to a constant weight at $65^{\circ} \mathrm{C}$ in an oven. The percent water content was estimated from the expression $\mathrm{WC}(\%)=100(\mathrm{FM}-\mathrm{DM}) / \mathrm{FM}$.

Topographic position of trees was established with a topographical total station. From topographic position and a digital elevation model with pixel size $10 \times 10$ m (Junta de Andalucía 2005), we calculated two topographic parameters for each tree: wetness index (Beven and Kirkby 1979) and flow length. Flow length was calculated as the maximum length that water arriving to a particular tree can cover. Topographic parameters were calculated with ArcGis v 9.2.

\section{Data analysis}

An ANOVA was performed to check if there were significant differences for water content in acorns depending on the year, month, location and tree. SPSS v. 18 was used for this analysis.

Our analysis considers that the following affect fresh acorn mass: location (CA, SB), tree (within location), pruning treatment (control, light, medium, heavy), year of production, and orientation within a tree $(\mathrm{N}, \mathrm{S}, \mathrm{E}, \mathrm{W})$. The dependent variable is the average fresh acorn mass in every tree, orientation, and year.

Thus, the initial model structure is expressed as:

$$
\begin{aligned}
y_{i j k l m}= & \mu+\alpha_{i}+b_{j(i)}+\tau_{k}+\gamma_{l}+\varepsilon_{m}+(\alpha \tau)_{i k}+(\alpha \gamma)_{i l} \\
& +(\alpha \varepsilon)_{i m}+(\tau \gamma)_{k l}+(b \gamma)_{j l(i)}+(b \varepsilon)_{j m(i)} \\
& +e_{i j k l m}
\end{aligned}
$$

with $y_{i j k l m}$ : mean fresh acorn mass $\left(\mathrm{g} \mathrm{acorn}^{-1}\right)$ at orientation $\mathrm{m}$ of tree $\mathrm{j}$ in location $i$ under the pruning treatment $k$ in the year $1 ; \mu$ : general mean; $\alpha_{i}$ : location fixed effect $(i=1,2) ; b_{j(i)}$ : tree (within location) random effect with $j=1,2, \ldots 16$ and $i=1,2$ with the initial hypothesis $b_{j(i)} \sim N\left(0, \sigma_{b}^{2}\right) ; k$ : pruning treatment fixed effect with $k=1,2,3,4 ; \varepsilon_{m}$ : orientation fixed effect with $m=1,2,3,4 ; \gamma_{1}$ : year fixed effect, with $i=1,2,3,4,5,6 ;(\alpha \tau)_{i k}$ : location $\times$ treatment interaction (fixed effect); $(\alpha \gamma)_{i l}$ : location $\times$ year interaction (fixed effect); $(\alpha \varepsilon)_{i m}$ : location $\times$ orientation interaction (fixed effect); $(\tau \gamma)_{k l}$ : treatment $\times$ year interaction (fixed effect); $(b \gamma)_{j l i}:$ tree $\times$ year 
interaction (random effect), with initial hypothesis $(b \gamma)_{j l i} \sim N\left(0, \sigma_{b y}^{2}\right) ;(b \varepsilon)_{j m i}:$ tree $\times$ orientation interaction (random effect), with initial hypothesis $(b \varepsilon)_{j m i} \sim N\left(0, \sigma_{b o}^{2}\right) ; \mathrm{e}_{i j k l}$ : error term with initial hypothesis $e_{i j k l} \sim N\left(0, \sigma_{e}^{2}\right)$.

In matrix form, $y=X a+Z b+e$, where $y$ is an $N$ $(=414) \times 1$ matrix with values of the dependent variable. $X$ is the design matrix with fixed effects; $a$ is the vector with coefficients of fixed effects; $Z$ is the random design matrix; $b$ is the random coefficients; and $e$ is the residual error vector. The variancecovariance matrix of $y$ is thus:

$$
\begin{aligned}
\operatorname{var}(y) & =\operatorname{var}(X a+Z b+e)=\operatorname{var}(Z b+e) \\
& =Z \operatorname{var}(b) Z^{\prime}+\operatorname{var}(e)=Z G Z^{\prime}+R=V
\end{aligned}
$$

We used the following process to select the best model structure.

\section{Selection of variance-covariance matrix} structure

To select the best variance-covariance structure (i.e. define elements of matrix $\mathbf{V}$ ) we assessed (1) the significance of the tree random effect; (2) the presence of spatial correlation between observations of trees within a location; (3) the significance of the tree $\times$ year interaction random effect; (4) the significance of the tree $\times$ orientation random effect; and (5) the presence of temporal correlation and heteroscedasticity between observations of different years for a certain tree and orientation. The first four steps are related to random effects, so we tested different structures of the $\mathbf{G}$ matrix. Step 5 is related to covariances between years and is a fixed effect, so we analyzed different structures of the $\mathbf{R}$ matrix.

To assess the spatial correlation structure, we considered an isotropic power covariance form: cov $\left(b_{j(i)}, b_{j^{\prime}(i)}\right)=\sigma_{b}^{2} \eta^{d j j^{\prime}}$ with $d_{j j^{\prime}}$ : distance between trees $j$ and $j^{\prime}$ in location $i$; $\sigma_{b}^{2}$ : variance component at tree level; and $\eta$ : parameter to be estimated.

For the variance-covariance between observations of different years for a certain tree and orientation, we considered the $\mathbf{R}$ matrix as a block diagonal, with blocks corresponding to each orientation within the tree. The following covariances between years for an orientation within a tree were tested (Wolfinger 1996 for a description of covariance structures): diagonal with homogeneous covariances, autoregressive of order 1, compound symmetry and compound symmetry heterogeneous, unstructured, unstructured diagonal, and unstructured with 2, 3, 4 and 5 bands, Toeplitz and Toeplitz with 2, 3, 4 and 5 bands, heterogeneous Toeplitz and heterogeneous Toeplitz with 2, 3, 4 and 5 bands, first-order antedependence, autoregressive moving average $(1,1)$, Huynh-Feldt, first order factor analytic, and power of the mean.

Variance components for each structure were estimated by restricted maximum likelihood (REML), with the best structure identified as follows. If one of the structures being compared was a reduction of the other structure, we used a likelihood ratio test, as the reduction of the statistic $-2 \times \log$ likelihood ( $-2 L L$ ), after introducing new covariance parameters follows a $\chi^{2}$ distribution with $\mathrm{n}$ degrees of freedom, where $\mathrm{n}$ is the number of new covariance parameters. We considered $\alpha=0.05$ to indicate an improvement in the covariance structure. In other cases, we considered the values of the Akaike information criteria (AIC, Akaike (1974)) with a lower value indicating a better model.

\section{Solution of fixed effects and level of significance}

After selecting the best variance-covariance structure, we estimated fixed effects by generalized least squares (GLS), with $\hat{\mathbf{a}}^{\mathbf{0}}=\left(\mathbf{X}^{\prime} \mathbf{V}^{-1} \mathbf{X}\right)^{-} \mathbf{X}^{\prime} \mathbf{V}^{-\mathbf{1}} \mathbf{y}$, and determined the significance of each effect with a $F$ test. Only significant effects (considering $\alpha=0.05$ ) were retained in the model. Comparison between levels of significant effects was performed with a Scheffé test.

\section{Introduction of covariates in significant levels}

For effects that were significant, we determined if the introduction of covariates at each level could explain a significant part of the variability, improve the characteristics of the model, and explain categorical effects. The levels and the covariates considered at each level were:

- Tree level, including variables related to:

- Tree size: circumference at $80 \mathrm{~cm}$ height (CH80) and canopy area (SCROWN).

- Topographic position of the tree: wetness index (WI) and Flow length (FLOWLEN).

- Competition between trees: 638 distancedependent competition indexes were calculated with INCO software (Vázquez-Piqué et al. 2001). The software can be downloaded 
from http://www.uhu.es/franciscoj.vazquez/ Programas.html. The formulation of the 638 calculated indexes can be consulted in Vázquez-Piqué and Pereira (2004).

- Tree $\times$ year $\times$ orientation level: to check if the production of acorns per tree per year for a particular orientation could negatively affect individual acorn mass, we calculated the variables:

- Total weight of acorns per tree $\left(\mathrm{g} \mathrm{m}^{-2}\right.$ of canopy area), per year, and by orientation (WAM2).

- Total number of acorns per tree (number of acorns $\mathrm{m}^{-2}$ of canopy area), per year and by orientation (NAM2).

- Location $\times$ year level: we considered the values of climatic variables per location and per year for the period 2001-2006. Daily climatic data for this period were obtained from the automatic weather stations of a network of the Consejería de Agricultura y Pesca (Regional Government of Andalusia, Spain). These stations were "Gibraleón" (37²4'49" $\mathrm{N}, 7^{\circ} 03^{\prime} 31^{\prime \prime} \mathrm{W}$, Altitude: $169 \mathrm{~m}$ ) for SB and "El Campillo" (37 $39^{\prime} 44^{\prime \prime} \mathrm{N}, 6^{\circ} 35^{\prime} 53^{\prime \prime} \mathrm{W}$, Altitude 406 $\mathrm{m})$ for CA. The variables that were considered were Air temperature $\left({ }^{\circ} \mathrm{C}\right)$, Precipitation $(\mathrm{mm})$, Relative humidity (\%), Solar radiation ( $\mathrm{MJ} \mathrm{m}^{-2} \mathrm{day}^{-1}$ ) and Potential Evapotranspiration (mm). From the raw daily data, we determined monthly, seasonal, and yearly values per location and per year.

- Year level: we considered the same climatic variables as in the location $\times$ year level, but used mean values between locations.

- Location level: as there are only two locations, no covariates were considered at location level.

The significance of the covariates was tested with a likelihood ratio test that considered the reduction of the $-2 \mathrm{LL}$ statistic after introducing the covariate. In this case, the variance component estimate was performed by maximum likelihood (ML). Statistical analysis was performed with SAS v.9.1.

\section{Results}

Significant differences were not found in acorn water content among trees $(F=0.77, p=0.770)$, months $(F=1.79, p=0.127)$, years $(F=0.797, p=0.751)$ and locations $(F=1.397, p=0.265)$. According to this result we decided to use fresh acorn mass in this study, which we consider more accurate because it is a direct measurement. Average acorn moisture content was $43.87 \%$ for SB plot and $43.33 \%$ for CA plot.

Overall measured average acorn mass was $3.60 \mathrm{~g}$ acorn $^{-1} \pm 1.93$ (SD) in CA, and $4.01 \mathrm{~g} \mathrm{acorn}^{-1} \pm$ 1.84 in SB. Maximum average weight in CA was in 2001 (4.78 $\mathrm{g} \mathrm{acorn}^{-1} \pm 1.79$ ) and in SB was in 2004 (4.43 $\left.\mathrm{g} \mathrm{acorn}^{-1} \pm 2.13\right)$. Minimum acorn mass in CA was in 2005 (2.12 $\left.\mathrm{g} \mathrm{acorn}^{-1} \pm 0.87\right)$ and in SB was in 2006 (3.02 $\left.\mathrm{g} \mathrm{acorn}^{-1} \pm 1.96\right)$. Maximum average acorn mass in every tree in CA was $4.93 \mathrm{~g}$ acorn $^{-1} \pm 2.04$ and in SB was 6.68 acorn $^{-1} \pm 1.70$. Maximum total acorn mass in CA was $20.20 \mathrm{~g}$ acorn $^{-1}$, and in SB was $11.91 \mathrm{~g} \mathrm{acorn}^{-1}$.

Variance-covariance structure

Table 5 shows the predicted variance components and the values of $-2 \mathrm{LL}$ and AIC for analysis of the significance of the tree random effect, tree $\times$ year interaction, tree $\times$ orientation interaction, and the spatial covariance structure. The likelihood ratio tests indicate that the tree random effect and the tree $x$ year interaction effect were highly significant $(p<0.0001)$, but that the tree $\times$ orientation effect was not significant $(p=0.160)$. The introduction of the spatial covariance structure was not significant (reduction in $-2 \mathrm{LL}=0.3 ; p=0.290$ ), indicating no spatial correlation between trees inside a location in acorn mass. Without considering the covariance between years of production in the orientation of a tree, the tree effect accounted for $29.9 \%$ of the variability not accounted for by fixed effects and the tree $\times$ year interaction accounted for $40.6 \%$ of the variability indicating the importance of considering these two effects in the model.

Table 6 shows the effect of retaining the model of tree and tree $\times$ year random effects, displaying a comparison of $-2 \mathrm{LL}$ and AIC used for the selection of the most adequate variance-covariance structure for the blocks of matrix $\mathbf{R}$ corresponding to tree orientation. The results provide strong evidence of non-homogeneous variance structure, as all the heterogeneous structures tested (the first 15 structures in Table 6) perform better than do the homogeneous structures. There is also evidence of a non-diagonal 
Table 5 Prediction of the variance components and the $-2 \times \log$ likelihood ( $-2 \mathrm{LL}$ ) and Akaike's information criteria (AIC) in models with a sequential introduction of tree, tree $\times$ year, and tree $\times$ orientation random effects and spatial covariance

\begin{tabular}{|c|c|c|c|c|c|c|c|}
\hline \multirow[t]{2}{*}{ Effect } & \multirow{2}{*}{$\begin{array}{l}\text { Variance } \\
\text { component }\end{array}$} & \multirow{2}{*}{$\begin{array}{l}\text { Fixed } \\
\text { effects }\end{array}$} & \multicolumn{5}{|c|}{ Random effects included in the model } \\
\hline & & & Tree & $\begin{array}{l}\text { Tree } \\
\text { Spatial covariance }\end{array}$ & Tree $\times$ year & $\begin{array}{l}\text { Tree } \\
\text { Tree } \times \text { year }\end{array}$ & $\begin{array}{l}\text { Tree } \\
\text { Tree } \times \text { year } \\
\text { Tree } \times \text { orientation }\end{array}$ \\
\hline Tree & $\begin{array}{l}\sigma_{b}^{2} \\
\eta\end{array}$ & & 1.1208 & $\begin{array}{l}1.1195 \\
0.88\end{array}$ & & 0.7811 & 0.7704 \\
\hline Tree $\times$ year & $\sigma_{b y}^{2}$ & & & & 1.8194 & 1.0617 & 1.0709 \\
\hline Tree $\times$ orientation & $\sigma_{b o}^{2}$ & & & & & & 0.0407 \\
\hline Residual & $\sigma_{e}^{2}$ & 2.0929 & 1.2990 & 1.2989 & 0.7575 & 0.7705 & 0.7325 \\
\hline Total variance & & 2.0929 & 2.4198 & 2.4184 & 2.5769 & 2.6123 & 2.6145 \\
\hline Statistics & & & & & & & \\
\hline$-2 \mathrm{LL}$ & & 1452.6 & 1323.7 & 1323.3 & 1271.2 & 1258.3 & 1257.3 \\
\hline AIC & & 1454.6 & 1327.7 & 1329.3 & 1275.2 & 1264.3 & 1265.4 \\
\hline
\end{tabular}

structure, because Heterogeneous Toeplitz with two bands (TOEPH2) and three bands (TOEPH3) perform significantly better than does the Unstructured diagonal (UND). Because TOEPH2 is significantly better than TOEPH3, this constitutes evidence of correlation in acorn mass between two consecutive years, but not between distant years. The selected variance-covariance structure for the blocks of the $\mathbf{R}$ matrix corresponding to $\mathrm{m}$ orientation of tree $\mathrm{j}$ is the heterogeneous Toeplitz with two bands: tree effect was $19-56 \%$ of the total variance (depending on year), and the percentage variance accounted for by tree $\times$ year effect was 8-24\% of the total variance (again depending on year). Table 8 shows the covariance between acorn mass data at different levels, that completely specifies the covariance structure.

Estimation and significance of fixed effects

Initial $p$ tests of the estimated fixed effects indicated that the treatment effect $(p=0.642)$, location $\times$ treatment

$$
\mathbf{R}_{\mathbf{j m}}=\left[\begin{array}{cccccc}
\sigma_{2001}^{2} & & & & & \\
\sigma_{2001} \sigma_{2002} \rho & \sigma_{2002}^{2} & & & & \\
0 & \sigma_{2002} \sigma_{2003} \rho & \sigma_{2003}^{2} & & & \\
0 & 0 & \sigma_{2003} \sigma_{2004} \rho & \sigma_{2004}^{2} & & \\
0 & 0 & 0 & \sigma_{2004} \sigma_{2005} \rho & \sigma_{2005}^{2} & \\
0 & 0 & 0 & 0 & \sigma_{2005} \sigma_{2006} \rho & \sigma_{2006}^{2}
\end{array}\right]
$$

Hence, the final structure of the variance-covariance matrix includes the tree and tree $\times$ year interaction random effects and variance-covariance between years for an orientation in a tree following a TOEPH2 structure. Table 7 shows the estimation of variance components including the tree and tree $\times$ year variance components. The residual estimated variance in year 2006 was much higher than that of other years. The estimation of correlation between consecutive years is 0.2502 . The percentage of variance accounted for by the $(p=0.488)$, location $\times$ orientation $(p=0.100)$, and treatment $\times$ year $(p=0.082)$ were not significant so the model was fitted without these effects. Table 9 shows the $F$ test data for the significant effects.

Figure 1 display the estimated values for the different levels of some of the significant fixed effects. The estimated acorn mass for SB (4.12 $\mathrm{g} \pm 0.31 \mathrm{~g})$ was significantly higher than that for CA $(3.17 \mathrm{~g} \pm 0.31 \mathrm{~g})$. Acorn mass in 2002 was significantly higher than in 
Table 6 Values of -2LL and AIC for different variance-covariance inside blocks of matrix R, with each block of $\mathbf{R}$ (dimension $6 \times 6$ ) corresponding to an orientation inside a tree

\begin{tabular}{|c|c|c|c|c|}
\hline \multirow[t]{2}{*}{ Order } & \multirow[t]{2}{*}{ Variance-covariance structure of $\mathrm{R}$ blocks } & \multirow{2}{*}{$\begin{array}{l}\text { Number of variance } \\
\text { components }\end{array}$} & \multicolumn{2}{|l|}{ Statistics } \\
\hline & & & $-2 \mathrm{LL}$ & AIC \\
\hline 1 & Heterogeneous Toeplitz with 2 bands & 7 & 1196.6 & 1214.6 \\
\hline 2 & Heterogeneous Toeplitz with 3 bands & 8 & 1196.1 & 1216.1 \\
\hline 3 & First order factor analytic & 12 & 1189.3 & 1217.3 \\
\hline 4 & Heterogeneous Toeplitz with 4 bands & 9 & 1195.8 & 1217.8 \\
\hline 5 & Heterogeneous Toeplitz with 5 bands & 10 & 1194.2 & 1218.2 \\
\hline 6 & Unstructured with 2 bands & 11 & 1193.8 & 1219.8 \\
\hline 7 & Heterogeneous Toeplitz & 11 & 1194.1 & 1220.1 \\
\hline 8 & Unstructured diagonal & 6 & 1204.2 & 1220.2 \\
\hline 9 & Compound symmetry heterogeneous & 7 & 1203.3 & 1221.3 \\
\hline 10 & Unstructured with 4 bands & 18 & 1181.8 & 1221.8 \\
\hline 11 & Unstructured with 3 bands & 15 & 1188.9 & 1222.9 \\
\hline 12 & Unstructured with 5 bands & 20 & 1179.4 & 1223.4 \\
\hline 13 & Unstructured & 21 & 1179.2 & 1225.2 \\
\hline 14 & Power of the mean & 2 & 1243.5 & 1251.5 \\
\hline 15 & Huynh-Feldt & 7 & 1236.2 & 1254.2 \\
\hline 16 & Toeplitz with 2 bands & 2 & 1251.8 & 1259.8 \\
\hline 17 & Autoregressive of order 1 & 2 & 1251.9 & 1259.9 \\
\hline 18 & Toeplitz with 3 bands & 3 & 1251.7 & 1261.7 \\
\hline 19 & Autoregressive moving average $(1,1)$ & 3 & 1251.7 & 1261.7 \\
\hline 20 & Toeplitz with 4 bands & 4 & 1251.7 & 1263.7 \\
\hline 21 & Diagonal with homogeneous variance & 1 & 1258.3 & 1264.3 \\
\hline 22 & Toeplitz with 5 bands & 5 & 1251.1 & 1265.1 \\
\hline 23 & Compound symmetry & 2 & 1257.3 & 1265.3 \\
\hline 24 & Toeplitz & 6 & 1251.1 & 1267.1 \\
\hline 25 & First order antedependence & 11 & Did not converge & \\
\hline
\end{tabular}

Structures are ordered by increasing AIC

Table 7 Estimated variance components of the selected variancecovariance structure, indicating total variance per year and percentage of variability accounted for by each effect

\begin{tabular}{|c|c|c|c|c|c|c|c|}
\hline \multirow[t]{2}{*}{ Year } & \multicolumn{4}{|c|}{ Variance components } & \multirow[t]{2}{*}{ Total } & \multicolumn{2}{|c|}{$\begin{array}{l}\% \text { of variability absorbed } \\
\text { by effect }\end{array}$} \\
\hline & Tree $\left(\sigma_{\mathrm{b}}^{2}\right)$ & Tree $\times$ year $\left(\sigma_{\text {by }}^{2}\right)$ & $\rho$ & Residual & & Tree & Tree $\times$ year \\
\hline 2001 & \multirow{6}{*}{1.0335} & \multirow{6}{*}{0.4556} & \multirow{6}{*}{0.2502} & 1.2665 & 2.7556 & 37.51 & 16.53 \\
\hline 2002 & & & & 0.7186 & 2.2077 & 46.81 & 20.64 \\
\hline 2003 & & & & 0.4812 & 1.9703 & 52.45 & 23.12 \\
\hline 2004 & & & & 0.9678 & 2.4569 & 42.07 & 18.54 \\
\hline 2005 & & & & 0.3492 & 1.8383 & 56.22 & 24.80 \\
\hline 2006 & & & & 3.8409 & 5.3300 & 19.39 & 8.55 \\
\hline
\end{tabular}

2003, and in 2003 was significantly higher than in 2005 (Fig. 1a). Acorn mass at the southern position was also significantly higher than in the other positions (Fig. 1b).
The examination of the residuals of the model (not shown) indicated that there is no evidence of biased estimation or heteroscedasticity in the estimation of acorn mass. 
Table 8 Specification of covariance between observations at different levels that completely describe the selected variancecovariance matrix used in the model

\begin{tabular}{|c|c|c|c|}
\hline Covariance between & $\begin{array}{l}\text { Covariance } \\
\text { expression }\end{array}$ & Remarks & Estimated value \\
\hline Two observations in different locations & - & & 0 \\
\hline Two observations in different trees inside a location & $\sigma_{\mathrm{b}}^{2} \eta^{\mathrm{djj} j^{\prime}}$ & Fail to reject $\mathrm{H}_{0}: \hat{\eta}=0$ & 0 \\
\hline $\begin{array}{l}\text { Two observations in the same tree in different } \\
\text { years and different orientations }\end{array}$ & $\sigma_{b}^{2}$ & & 1.0335 \\
\hline $\begin{array}{l}\text { Two observations in the same tree in the same } \\
\text { year and different orientations }\end{array}$ & $\sigma_{b}^{2}+\sigma_{b y}^{2}$ & & 1.4891 \\
\hline $\begin{array}{l}\text { Two observations in the same tree in different } \\
\text { and not consecutive years and the same orientation }\end{array}$ & $\sigma_{b}^{2}+\sigma_{b o}^{2}$ & Fail to reject $\mathrm{H}_{0}: \hat{\sigma}_{b o}^{2}=0$ & 1.0335 \\
\hline $\begin{array}{l}\text { Two observations in the same tree in different } \\
\text { but consecutive years and the same orientation }\end{array}$ & $\sigma_{b}^{2}+\sigma_{b o}^{2}+\sigma_{1} \sigma_{1}^{\prime} \rho$ & Fail to reject $\mathrm{H}_{0}: \hat{\sigma}_{b o}^{2}=0$ & $\begin{array}{l}1=2001, l^{\prime}=2002: 1.7292 \\
1=2002,1^{\prime}=2003: 1.6377 \\
1=2003,1^{\prime}=2004: 1.6613 \\
1=2004,1^{\prime}=2005: 1.6360 \\
1=2005,1^{\prime}=2006: 1.7803\end{array}$ \\
\hline
\end{tabular}

Table 9 Significance of the significant fixed effects for the final selected model

\begin{tabular}{llrrr}
\hline Effect & Num DF & Den DF & \multicolumn{1}{c}{$F$} & $\operatorname{Pr}>F$ \\
\hline Location & 1 & 29.9 & 8.47 & 0.0068 \\
Year & 5 & 58.0 & 7.71 & $<0.0001$ \\
Orientation & 3 & 132.0 & 5.18 & 0.0020 \\
Location $\times$ year & 4 & 54.5 & 10.06 & $<0.0001$
\end{tabular}

Num DF numerator degrees of freedom, Den DF denominator degrees of freedom, $F F$ statistic

Covariates significance at different levels

- Tree level. None of the variables related to tree size $(\mathrm{CH} 80, p=0.650$; SCROWN, $p=0.50$ ) or topographic position of the tree (WI, $p=0.820$; FLOWLEN, $p=0.980$ ) explain a significant part of the variability at the tree level. In addition, none of the 638 competition indices was significant.

- Tree $\times$ year $\times$ orientation level. The covariate NAM2 (total number of acorns per tree, year, and orientation per $\mathrm{m}^{2}$ of canopy area) was significant $(p=0.013)$, with a reduction in the $-2 \mathrm{LL}$ of 1,239.2-1,233.1, and a reduction in AIC from $1,285.2$ to $1,281.1$. The sign of the estimated coefficient $(-0.00204)$ indicates that as more acorns are produced, the weight of acorns is less.
The covariate WAM2 (total weight of acorns per tree, year, and orientation per $\mathrm{m}^{2}$ of canopy area) was not significant $(p=0.539)$.

- Year level. Table 10 shows the climatic covariates with the highest level of significance $(p<0.0001)$. These variables are related to temperature, precipitation and evapotranspiration. The results show that higher minimum and mean temperatures in winter and early spring were related to greater acorn mass. In contrast, higher minimum temperatures in May and August and higher temperature maxima in September were associated with reduced acorn mass. In particular, September weather plays an important role explaining the variability of acorn mass between years. Higher relative humidity in this month and greater precipitation were all associated with greater acorn mass. Nevertheless, in mid-summer, higher values of potential evapotranspiration were associated with enhanced acorn mass. The mean of the maximum temperature during the year explains better the differences, with higher temperatures associated with lower acorn mass.

- Location $\times$ year level. Table 11 shows the most significant covariates at the location $\times$ year level. As above, September had the most significant variables, and lower values of mean temperature, mean minimum temperature, solar radiation, 

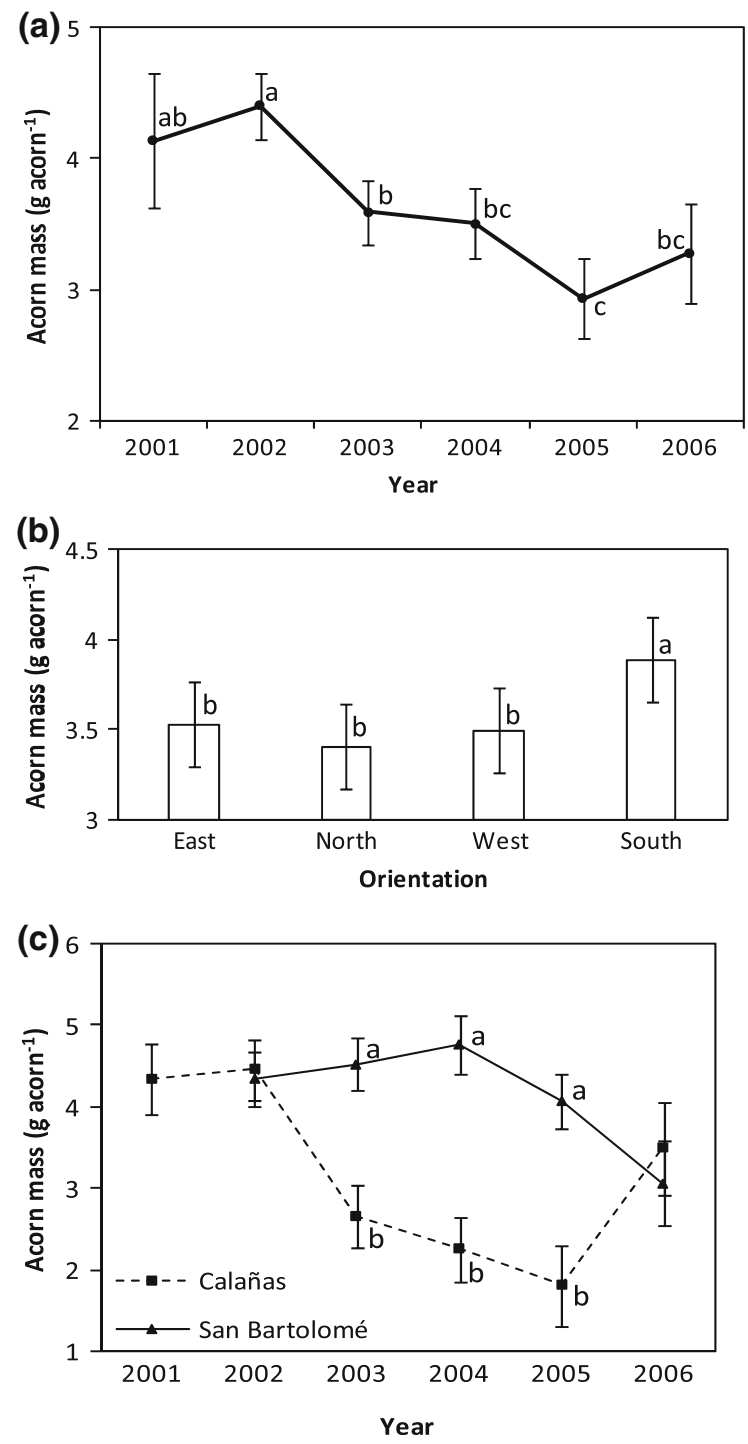

Fig. 1 Estimated acorn mass per year (a), per orientation (b) and per year and location (c). Bars indicate the standard errors. Values with the same letter indicate no-significant differences. In Fig. 1c different letters indicate significant differences between locations in a particular year

potential evapotranspiration and higher relative humidity in this month were all associated with greater acorn mass. Our results also indicate that higher temperatures in December and lower in autumn were associated with increased acorn mass. Greater precipitation and higher minimum temperature in April were associated with reduced acorn mass. Higher solar radiation in July and maximum temperature in June were associated with enhanced acorn mass, but higher summer potential evapotranspiration was associated with reduced acorn mass.

\section{Discussion}

Average estimated acorn mass in this study (3.60 $\mathrm{g}$ acorn $^{-1}$ for CA, $4.01 \mathrm{~g} \mathrm{acorn}^{-1}$ for SB) was within the range reported previously $\left(1.2-6.5 \mathrm{~g} \mathrm{acorn}^{-1}\right.$ ) for Holm Oak (Gea-Izquierdo et al. 2006). The SB location was significantly more favorable for acorn production. This location had better edaphic conditions $(33 \mathrm{~cm}$ mean depth for CA and $67 \mathrm{~cm}$ mean depth for SB, and the presence of graywacke as parental material in $\mathrm{CA}$ ) and climatic conditions (2 frost months in $\mathrm{SB}$ and four in $\mathrm{CA}$ ). In the $\mathrm{CA}$ location, the presence of graywackes (a hard bed rock) and slates probably limits the development and number of deep tap roots that can access the local groundwater reservoir. Paço et al. (2009), also working in a dehesa, found a high resilience of Holm Oaks to drought. The cited authors found that the decline in transpiration during very dry years (2004 and 2005 in their study area) was only $16 \%$, much smaller than the decline in annual rainfall. These results can be explained by direct permanent access of the roots of Holm Oak to the local groundwater reservoir (David et al. 2007).

The largest difference in physiological tree status between the CA and SB locations appeared in 2005, which had the most severe drought in our study area for the last 60 years (European Environmental Agency 2007). The effect of drought stress could have been exacerbated by "oak decline" in the region, resulting from a combination of exchangeable biotic and/or non biotic factors that leads to a gradual deterioration of the physiological status of plants (Manion 1991). The factors causing the decay include severe, recurrent drought; seasonal flooding, atmospheric pollution, tree treatments and land use changes in dehesas and the presence of drilling insects and fungal pathogens such as Phytophtora cinnamomi; Biscougniauxia mediterranea and Botryosphaeria stevensii or the bacterium Erwinia quercinea (Navarro et al. 2004; Tapias et al. 2008). Under these conditions, the CA location was more adversely affected in 2005, when the mean 
Table 10 Covariates at the year level with the highest significance $(p<0.001)$ and values of the estimated coefficient, $-2 \times 10 g$ likelihood (-2LL) and Akaike's information criteria (AIC)

\begin{tabular}{|c|c|c|c|c|c|}
\hline Covariate & Coefficient & $F$ value & Prob $>F$ & $-2 \mathrm{LL}$ & AIC \\
\hline Tmmax_year & -1.67 & 19.75 & $<0.0001$ & 1278.06 & 1308.06 \\
\hline P_September & 0.01 & 17.71 & 0.0001 & 1279.80 & 1309.80 \\
\hline Tmin_March & 0.25 & 16.94 & 0.0001 & 1280.00 & 1310.00 \\
\hline Tmin_February & 0.26 & 16.07 & 0.0002 & 1280.99 & 1310.99 \\
\hline ET_July & 0.07 & 15.50 & 0.0002 & 1281.54 & 1311.54 \\
\hline Hmmax_September & 0.08 & 14.59 & 0.0003 & 1282.30 & 1312.30 \\
\hline Tmin_spring & 0.26 & 12.88 & 0.0006 & 1283.39 & 1313.39 \\
\hline Tmax_September & -0.13 & 13.10 & 0.0005 & 1283.46 & 1313.46 \\
\hline Hmean_September & 0.05 & 13.06 & 0.0006 & 1283.59 & 1313.59 \\
\hline Tmin_May & -0.25 & 12.46 & 0.0006 & 1283.77 & 1313.77 \\
\hline Tmin_year & 0.22 & 12.86 & 0.0007 & 1283.77 & 1313.77 \\
\hline Tmin_winter & 0.22 & 12.72 & 0.0007 & 1283.93 & 1313.93 \\
\hline Tmin_January & 0.14 & 12.56 & 0.0008 & 1283.97 & 1313.97 \\
\hline Tmean_February & 0.28 & 12.25 & 0.0009 & 1284.12 & 1314.12 \\
\hline Tmmin_February & 0.25 & 12.21 & 0.0009 & 1284.18 & 1314.18 \\
\hline Hmmin_September & 0.04 & 12.21 & 0.0009 & 1284.24 & 1314.24 \\
\hline Tmin_August & -0.32 & 12.37 & 0.0008 & 1284.69 & 1314.69 \\
\hline
\end{tabular}

Values of -2LL and AIC for the model without the covariate were 1,295.3 and 1,323.3 respectively

Tmmax mean of the maximum temperatures $\left({ }^{\circ} \mathrm{C}\right), P$ precipitation $(\mathrm{mm})$, Tmin minimum temperature $\left({ }^{\circ} \mathrm{C}\right)$, ET potential evapotranspiration $(\mathrm{mm}), \mathrm{Hmmax}$ mean of the maximum relative humidity $(\%)$, Tmax maximum temperature $\left({ }^{\circ} \mathrm{C}\right), H$ mean mean relative humidity (\%), Tmean mean temperature $\left({ }^{\circ} \mathrm{C}\right)$, Tmmin mean of the minimum temperatures $\left({ }^{\circ} \mathrm{C}\right), \mathrm{Hmmin}$ mean of the minimum relative humidity $(\%)$

mid-summer water potential was $-4.10 \mathrm{MPa}$, whereas that in $\mathrm{SB}$ was never below $-3.70 \mathrm{MPa}$ (Alejano et al. 2008).

Acorn mass varied significantly among individual trees and across years. A similar effect was observed by Koenig et al. (2009) in California, in a study on $Q$. lobata, a Mediterranean deciduous oak. We found that acorn mass varied significantly among different trees of $Q$. ilex, similar to the results of García-Mozo et al. (2007). In particular, we found that tree effect accounted for $19.39 \%$ (2006) to $56.22 \%$ (2005) of the variability not explained by fixed effects. In other words, the weight of acorns is more similar within a tree than between trees. This led us to search for covariates at the tree level. Nevertheless, none of the covariates at this level were significant, a result also observed by Koenig et al. (2009), who, however, considered only the tree size parameter $\mathrm{DBH}$ for correlation with $Q$. lobata acorn mass. We found no spatial correlation between trees in the same location, indicating that nearby trees are not more similar in acorn mass than are distant trees.
These two observations (lack of spatial correlation and lack of significant effect of covariates at tree level) suggest that the tree effect on acorn mass may have a genetic basis. This is supported by Soto et al. (2005), who found no significant genetic structure for mature Holm Oak trees, and only a weak genetic structure at short distances (up to $30 \mathrm{~m}$ ) before removing younger stems from analysis; obviously because mature $Q$. ilex trees reproduce vegetatively by rooting. This result suggests a lack of significant inbreeding among offspring. More studies in this direction would be needed to entirely support this hypothesis.

Our observation that acorn mass was different in various years can be explained by climate. Climatic conditions at the end of the summer drought (September), the fattening period for acorns (Siscart et al. 1999) when water stress is greater, was the most significant climatic period in our model. Our results show that parameters associated with more intense drought in September (high temperature, evapotranspiration and radiation; and low precipitation) is 
Table 11 Covariates at the location $\times$ year level with highest significance $(p<0.0001)$ and values of the estimated coefficient, $-2 \times \log$ likelihood (-2LL) and Akaike's information criteria (AIC)

\begin{tabular}{|c|c|c|c|c|c|}
\hline Covariate & Coefficient & $F$ value & Prob $>F$ & $-2 \mathrm{LL}$ & AIC \\
\hline Tmean_September & -3.09 & 38.66 & $<0.0001$ & 1243.39 & 1283.39 \\
\hline P_April & -0.06 & 37.96 & $<0.0001$ & 1244.41 & 1284.41 \\
\hline ET_September & -0.31 & 36.37 & $<0.0001$ & 1244.50 & 1284.50 \\
\hline Hmean_September & 0.85 & 36.18 & $<0.0001$ & 1244.94 & 1284.94 \\
\hline Hmmin_February & -0.44 & 34.52 & $<0.0001$ & 1246.28 & 1286.28 \\
\hline Rmean_July & 4.75 & 32.74 & $<0.0001$ & 1247.82 & 1287.82 \\
\hline Hmmax_September & 0.42 & 33.27 & $<0.0001$ & 1248.01 & 1288.01 \\
\hline ET_summer & -0.15 & 32.91 & $<0.0001$ & 1248.05 & 1288.05 \\
\hline Tmmin_September & -2.02 & 33.52 & $<0.0001$ & 1249.15 & 1289.15 \\
\hline Rmean_February & 2.75 & 28.20 & $<0.0001$ & 1251.34 & 1291.34 \\
\hline Rmean_December & 2.25 & 30.33 & $<0.0001$ & 1251.87 & 1291.87 \\
\hline Rmean_September & -3.45 & 26.24 & $<0.0001$ & 1252.39 & 1292.39 \\
\hline P_December & 0.05 & 29.18 & $<0.0001$ & 1253.28 & 1293.28 \\
\hline Tmmin_autumn & -1.79 & 21.89 & $<0.0001$ & 1257.12 & 1297.12 \\
\hline Tmmax_December & 2.25 & 23.94 & $<0.0001$ & 1257.42 & 1297.42 \\
\hline Tmin_December & 1.09 & 18.96 & $<0.0001$ & 1258.13 & 1298.13 \\
\hline Tmean_autumn & -2.54 & 18.71 & $<0.0001$ & 1258.74 & 1298.74 \\
\hline Tmax_June & 0.69 & 19.74 & $<0.0001$ & 1258.95 & 1298.95 \\
\hline Tmin_April & -1.06 & 21.45 & $<0.0001$ & 1259.18 & 1299.18 \\
\hline
\end{tabular}

Values of -2LL and AIC for the model without the covariate was 1,275.7 and 1,313.7 respectively

Tmean mean temperature $\left({ }^{\circ} \mathrm{C}\right), P$ precipitation $(\mathrm{mm}), E T$ potential evapotranspiration $(\mathrm{mm}), H$ mean mean relative humidity $(\%)$, $H$ mmin mean of the minimum relative humidity (\%), Rmean mean solar radiation $\left(\mathrm{MJ} \mathrm{m}^{-2}\right.$ day $\left.^{-1}\right), H$ mmax mean of the maximum relative humidity $(\%), T$ mmin mean of the minimum temperatures $\left({ }^{\circ} \mathrm{C}\right), T$ mmax mean of the maximum temperatures $\left({ }^{\circ} \mathrm{C}\right), T$ min minimum temperature $\left({ }^{\circ} \mathrm{C}\right), T$ max maximum temperature $\left({ }^{\circ} \mathrm{C}\right)$

related with lighter acorns. In summers when drought was not as strong, higher maximum temperature in June and greater radiation in July were associated with heavier acorns.

Acorns on the southern side of trees were significantly heavier than those at other positions. Oliveira et al. (1996) found that orientation within the crown influenced the maximal diurnal course of stomatal conductance, which was a compromise between optimal environmental conditions and time of day, although the daily stomatal contribution was similar in all sections of the canopy. Although within-crown variability was not evident during periods of environmental stress (e.g., summer), differences among crown sections were apparent over the intensive growth period (spring) (Oliveira et al. 1996). We suggest that this situation may also apply in the autumn, the period when acorns develop in the Mediterranean areas. Acorns from the southern sides of trees may be better for growth of seedlings in a nursery because heavier seeds would be expected to show better germination (Jakobsson and Eriksson 2000), improved survival (Leishman et al. 2000), increased frost resistance, and to be more tolerant to environmental stress (Aizen and Woodcock 1992).

The location $\times$ year interaction had a significant effect on acorn mass. In the CA location, acorn mass was maximal in 2001 and 2002, minimal in 2005 (a very dry and cold year), and was high again in 2006, when the climate was more favorable. In the SB location, acorn mass was maximal in 2004, falling in 2005 and still in 2006. In 2006, there was also higher variance in acorn mass from both locations. The total acorn crop was also very low in 2006 and fieldwork indicated that many acorns were affected by insects. Yu et al. (2003) also found higher insect-infestation rates in low crop years for Quercus. The abundance of infected acorns may 
also explain the peak in variance of acorn mass in 2006.

The covariate "total number of acorns" was significantly and negatively associated with acorn mass. The tradeoff between offspring weight and number has been a foundation of much of the theoretical work on life history patterns (Smith and Fretwell 1974; Wilbur 1977). Many authors have observed an inverse relationship between offspring size and number in diverse plant species (Jakobsson and Eriksson 2000; Leishman et al. 2000; Abrahamson and Layne 2003). In contrast, in a study of $Q$. lobata, Koenig et al. (2009) found no such tradeoff between seed number and size, and suggested that factors other than resources available to individual trees determined the relationship between seed size and number.

The effect of pruning and the interactions of location $\times$ pruning treatment and pruning treatment $\times$ year were not significant. In other words, pruning practices did not affect acorn mass. Thus, in agreement with the results of Alejano et al. (2008), our results indicate that the decision to prune Holm Oaks in the dehesa should be determined by other criteria, such as tree health, economics, or the need for fuel wood production.

Acknowledgments This study was sponsored by the Department of Innovation, Science and Business of the Regional Government of Andalusia, Spain (ref: C03-192) and by MEC-INIA, Spain (ref: SUM2006-00026-00-00). The authors also wish to thank AECI for funding the $\mathrm{PhD}$ student Felipe Carevic.

\section{References}

Abrahamson WJ, Layne JN (2003) Long term patterns of acorn production for five oak species in xeric Florida uplands. Ecology 84(9):2476-2492

Afzal-Rafii Z, Dodd RS, Pelleau Y (1992) Mediterranean evergreen oak diversity: morphological and chemical variation of acorns. Can J Bot 70(7):1459-1466. doi:10.1139/b92-184

Aizen MA, Woodcock H (1992) Latitudinal trends in acorn size in Eastern North American species of Quercus. Can J Bot 70(6):1218-1222. doi:10.1139/b92-153

Akaike H (1974) A new look at the statistical model identification. IEEE Trans Autom Control 19(6):716-723. doi:10.1109/TAC.1974.1100705

Alejano R, Alaejos J, Torres E (2004) Pruning quantification and biomass production in two holm oak dehesas of southwest Spain. In: Arianoutsou M, Papanastasis VP (eds)
Proceedings of the 10th international conference on Mediterranean climate ecosystems: ecology, conservation and management of Mediterranean climate ecosystems, Rodhes, Greece, 25 Apr-1 May 2004. Millpress, Amsterdam, pp 40-49

Alejano R, Tapias R, Fernández M, Torres E, Alaejos J, Domingo J (2008) Influence of pruning and the climatic conditions on acorn production in holm oak (Quercus ilex L.) dehesas in SW Spain. Ann For Sci 65(2):209(1-9). doi: 10.1051/forest:2007092

Álvarez S, Morales R, Bejarano L, Durán A (2002) Producción de bellota en la dehesa salmantina. Actas de la XLII Reunión Científica de la SEEP, Lérida, pp 645-649

Beven KJ, Kirkby MJ (1979) A physically based, variable contributing area model of basin hydrology. Hydrol Sci Bull 24(1):43-69

Bondeau A, Kicklighter DW, Kaduk J (1999) Comparing global models of terrestrial net primary productivity (NPP): importance of vegetation structure on seasonal NPP estimates. Glob Change Biol 5:35-45

Bonfil C (1998) The effects of seed size, cotyledon reserves and herbivory on seedling survival and growth in Quercus rugosa and Q. laurina (Fagaceae). Am J Bot 85(1):79-87

Cañellas I, Roig S, Montero G (2006) Pruning influence on acorn yield in cork oak open woodland. In: MosqueraLosada MR, McAdam J, Rigueiro-Rodríguez A (eds) International Congress on Silvopastoralism and Sustainable Management: Silvopastoralism and Sustainable Land Management, Lugo, Spain, April 2006. CABI Publishing, Oxfordshire, pp 110-111

Cañellas I, Roig S, Poblaciones MJ, Gea-Izquierdo G, Olea L (2007) An approach to acorn production in Iberian dehesas. Agrofor Syst 70:3-9

Carbonero MD, Navarro R, Fernández P (2002) Evaluación de la producción y del calibre de bellotas de Quercus ilex L. subsp. ballota (Desf) Samp. a lo largo de un ciclo de poda: Resultados de la campaña 2000-2001. In: Chocarro C, Santiveri F, Fanlo R, Bovet I, Lloveras J (eds) XLII Reunión de la Sociedad Española para el Estudio de los Pastos: Producción de pastos, forrajes y céspedes, Lleida, Spain, 6-10 May 2002. Ediciones de la Universidad de Lleida, Lleida, pp 633-638

Carbonero MD, Fernández-Ranchal A, Fernández-Rebollo $\mathrm{P}$ (2008) La producción de bellota en la dehesa. In: Fernández-Rebollo $\mathrm{P}$, Carbonero MD, Blázquez A (eds) La Dehesa en el Norte de Córdoba. Perspectivas futuras para su conservación. Universidad de Córdoba, Cordoba

Consejeria de Medio Ambiente (2004) Manual de Ordenación de Montes de Andalucía. Junta de Andalucía, Sevilla

David TS, Henriques MO, Kurz-Besson C, Nunes J, Valente F, Vaz M, Pereira JS, Siegwolf R, Chaves MM, Gazarini LC, David JS (2007) Water-use strategies in two co-occurring Mediterranean evergreen oaks: surviving the summer drought. Tree Physiol 27:793-803

Debazac EF (1983) Temperate broad-leaved evergreen forest of the Mediterranean Region and Middle East. In: Ovington JD (ed) Ecosystems of the world 10: temperate broad-leaved evergreen forests. Elsevier, Amsterdam, pp 107-123

Emlen JM (1966) The role of time and energy in food preference. Am Nat 100:611-617 
European Environmental Agency (2007) Climate change and water adaptation issues. European Environmental Agency Technical Report no 2/2007

García-Mozo H, Gómez-Casero MT, Domínguez E, Galán C (2007) Influence of pollen emission and weather-related factors on variations in holm-oak (Quercus ilex subsp. ballota) acorn production. Environ Exp Bot 61(1):35-40. doi:10.1016/j.envexpbot.2007.02.009

Gea-Izquierdo G, Cañellas I, Montero G (2006) Acorn production in Spanish holm oak woodlands. Investig Agrar Sist Recur For 15(3):339-354

Greenberg CH (2000) Individual variation in acorn production by five species of Southern Appalachian oaks. For Ecol Manag 132:199-210. doi:10.1016/S0378-1127(99)00226-1

Healy WM, Lewis AM, Boose EF (1999) Variation of red oak acorn production. For Ecol Manag 116:1-11

Hidalgo-Fernández P, Heras MA (2003) The effect of climate fluctuations on tree rings of Pinus pinaster Ait. and Quercus ilex subsp. ballota (Desf.) Samp. In: Ruiz MB, Dorado A, Valdeolmillos MJ, Gil T, Bardají I, De Bustamante C, Martínez I (eds) Quaternary climatic changes and environmental crises in the Mediterranean Region. Universidad de Alcalá de Henares, Madrid, pp 7-12

Jakobsson A, Eriksson O (2000) A comparative study of seed number, seed size, seedling size and recruitments in grasslands plants. Oikos 88(3):494-502

Junta de Andalucía (2005) Modelo Digital del Terreno de Andalucía: Relieve y Orografía. Junta de Andalucía, Sevilla

Koenig WD, Mumme RL, Carmen WJ, Stanback MT (1994) Acorn production by oaks in coastal California: variation between and among years. Ecology 75(1):99-109

Koenig WD, Knops JMH, Carmen WJ, Sage D (2009) No trade-off between seed size and number in the valley oak Quercus lobata. Am Nat 173:682-688. doi:10.1086/ 597605

Leishman MR, Wright IJ, Moles AT, Westoby M (2000) The evolutionary ecology of seed size. In: Fenner M (ed) Seeds: the ecology of regeneration in plant communities, 2nd edn. CABI Publishing, Wallingford, pp 31-57

Manion PD (1991) Tree disease concepts. Prentice-Hall, London

Martin A, Infante JM, García J, Merino J, Fernández R (1998) Producción de bellotas en montes y dehesas del Suroeste Español. Pastos XXVIII 2:237-248

Navarro R, Fernández P, Trapero A, Caetano P, Romero MA, Sánchez ME, Fernández A, Sánchez I, López G (2004) Los procesos de decaimiento de encinas y alcornoques. Monografia. Convenio Consejería de Medio Ambiente Universidad de Córdoba. Dirección General de Gestión del Medio Natural. Consejería de Medio Ambiente. Junta de Andalucía, Andalucia

Oliveira G, Werner C, Correia O (1996) Are ecophysiological responses influenced by crown position in cork-oak? Ann For Sci 53:235-241

Paço T, David TS, Henriques MO, Pereira JS, Valente F, Banza J, Pereira FL, Pinto C, David JS (2009)
Evapotranspiration from a Mediterranean evergreen oak savannah: the role of trees and pasture. J Hydrol 369:98-106. doi:10.1016/j.jhydrol.2009.02.011

Poblaciones MJ, López-Bellido R, Olea L, Benito C (2006) Evaluation of the production of acorns of oaks (Quercus ilex L. subsp. ballota) from southwest of Extremadura, Spain. In: Mosquera MR, McAdam J, Rigueiro A (eds) Silvopastoralism and sustainable land management. CABI Publishing, Oxfordshire

Pons J, Pausas J (2007) Rodent acorn selection in a Mediterranean oak landscape. Ecol Res 22(4):535-541

Rodríguez-Estévez V, García A, Peña F, Gómez AG (2009) Foraging of Iberian fattening pigs grazing natural pasture in the dehesa. Livest Sci 120(1-2):135-143. doi:10.1016/ 1.livsci.2008.05.006

San Miguel A (1994) La dehesa española. Origen, tipología, características y gestión. Fundación Conde del Valle de Salazar, Escuela Técnica Superior de Ingenieros de Montes, Madrid

Siscart D, Diego V, Lloret F (1999) Acorn ecology. In: Rodá F, Retana J, Gracia CA, Bellot J (eds) Ecology of Mediterranean evergreen oak forests. Springer Verlag, Berlin, pp 75-86

Smith CC, Fretwell SD (1974) The optimal balance between size and number of offspring. Am Nat 108:499-506

Soto A, Lorenzo Z, Gil L (2005) Fine-scale genetic structure in a Quercus suber L.-Q. ilex L. mixed dehesa. In: Vázquez-Piqué J, Pereira H, González-Pérez A (eds) Suberwood: new challenges for the integration of cork oak forests and products. Universidad de Huelva Publicaciones, Huelva, pp 27-36

Tapias R, Moreira AC, Fernández M, Sáenz A, Domingos AC, Melo E, Cravador A (2008) Variability in the tolerant/ resistance of Quercus suber L. seedlings to Phytophthora cinnamomi Rands. Evaluation of survival. In: VázquezPiqué J, Pereira H, González-Pérez A (eds) Suberwood: new challenges for the integration of cork oak forests and products. Universidad de Huelva Publicaciones, Huelva, pp 237-246

Vázquez-Piqué J, Pereira H (2004) Modelos de crecimiento en diámetro para alcornocales del centro y sur de Portugal. Cuad Soc Esp Cien For 18:219-226

Vázquez-Piqué J, Lago J, González-Pérez A (2001) INCO: programa para el cálculo de índices de competencia de especies forestales. In: Junta de Andalucía (ed) Actas del III Congreso Forestal Español, Granada, 25-28 September 2001, vol V. Coria Gráfica, Sevilla, pp 517-524

Wilbur HM (1977) Propagule size, number and dispersion pattern in Ambystoma and Asclepias. Am Nat 111:43-68

Wolfinger RD (1996) Heterogeneous variance-covariance structures for repeated measures. J Agric Biol Environ Stat 1:205-230

Yu X, Zhou H, Luo T (2003) Spatial and temporal variations in insect-infested acorn fall in a Quercus liaotungensis forest in north China. Ecol Res 18:155-164 